\title{
Sistem Aplikasi Location Based Service untuk Pengembangan Kota Cerdas
}

\author{
Agus Sukerta, Linawati, dan NMAE Dewi Wirastuti
}

\begin{abstract}
One way to accomplish the smart city is by utilizing application that build interaction between society and the government while providing the benefits to all stakeholders. This application systems should be reached easily and relatively cheap for the society, and they can be used anytime, anywhere. This paper describes how to develop applications that implement the Location Based Services (LBS) for Development of Smart City to build the Public Complaints Service Application System (PCSAS). The PCSAS was designed, built and then tested. This PCSAS was built with Web-based Client-Server architecture. On the client side using a web interface or mobile with Android operating system. This application uses a valid e-mail as a condition of enrollment, while accommodating Social Media interface particularly Facebook and Twitter to get into the system. The result of the use of this application system was an interaction between the community and the government in handling public complaints. Location information problems in the field may soon be known precisely by coordinates, so that the handling can be done quickly and with sufficient preparation equipment based on the information of the real conditions in the field in the form of photos and videos that are included in the complaint.
\end{abstract}

Index Term - Smart City, LBS, Public Complaints, Web and Mobile Application.

Abstrak-Salah satu cara pengembangan kota cerdas adalah dengan mengembangkan sistem aplikasi yang membangun interaksi antara masyarakat dan pemerintah sekaligus memberikan manfaat kepada para pemangku kepentingan. Sistem aplikasi ini haruslah dapat dijangkau dengan mudah dan relatif murah oleh masyarakat, dapat digunakan kapan saja, dimana saja. Makalah ini menjelaskan tentang bagaimana mengembangkan Sistem Aplikasi yang menerapkan Layanan Berbasis Lokasi untuk Pengembangan Kota Cerdas dengan membangun Sistem Aplikasi Pengaduan Masyarakat. Sistem aplikasi ini dirancang, dibangun dan kemudian diujicobakan. Sistem Aplikasi Pengaduan Masyarakat ini dibangun dengan arsitektur Client-Server berbasis web. Pada sisi Client menggunakan antarmuka web maupun mobile dengan sistem operasi Android. Aplikasi ini menggunakan email valid sebagai syarat pendaftaran, dengan tetap mengakomodir antarmuka Social Media khususnya Facebook dan Twitter untuk dapat masuk ke dalam sistem. Hasil dari penggunaan sistem aplikasi ini adalah terjadinya sebuah interaksi antara Masyarakat dan

Agus Sukerta adalah Magister Teknik Elektro, Program Pasca Universitas Udayana (e-mail: agusukerta@gmail.com).

Linawati adalah dengan Magister Teknik Elektro Program Pasca Sarjana Universitas Udayana (e-mail: linawat@unud.ac.id).

NMAE Dewi Wirastuti adalah Magister Teknik Elektro Program Pasca Sarjana Universitas Udayana (e-mail: arydev_02@yahoo.com).
Pemerintah dalam penanganan pengaduan masyarakat. Informasi lokasi permasalahan di lapangan dapat segera diketahui secara tepat berdasarkan koordinatnya, sehingga penanganannya dapat dilakukan dengan segera dan dengan persiapan peralatan yang cukup berdasarkan informasi kondisi riil di lapangan dalam bentuk foto maupun video yang disertakan dalam pengaduan.

Kata kunci- Pota Cerdas, LBS, Pengaduan Masyarakat, Aplikasi Web dan Mobile.

\section{PENDAhUluan}

$\mathrm{P}$ EMANFAATAN Teknologi Informasi dalam Pemerintahan khususnya Pemerintah Kabupaten Badung telah dimulai sejak lama. Berbagai Sistem Informasi telah dibangun guna menyederhanakan tugas Satuan Kerja Perangkat Daerah (SKPD) Pemerintah Kabupaten sekaligus meningkatkan pelayanan kepada masyarakat. Sistem ini ada yang digunakan secara internal dalam lingkungan pemerintah kabupaten maupun yang dapat diakses oleh masyarakat luas.

Penggunaan Sistem Informasi untuk setiap SKPD Pemerintah Kabupaten Badung didasarkan kepada tugas pokok dan fungsinya. Khusus untuk Dinas Perhubungan Komunikasi dan Informatika Kabupaten Badung memiliki tugas pokok dan fungsi yang tertuang dalam Visi dan Misi SKPD. Dalam pelayanan kepada masyarakat, Dinas Perhubungan Komunikasi dan Informatika memiliki salah satu Misi yaitu Meningkatkan pemanfaatan Teknologi Informasi secara efektif dan efisien[1]. Adapun perwujudan pelaksanaan Misi tersebut adalah menjalin sebuah komunikasi dan menyediakan informasi yang baik, dengan dan untuk masyarakat, dengan memanfaatkan teknologi informasi.

Penanggulangan bencana alam, pelaksanaan kegiatan pemeliharaan fasilitas umum, kebersihan dan penyelamatan lingkungan merupakan tanggung jawab Pemerintah dan masyarakat. Diperlukan informasi lokasi dan kondisi riil di lapangan dalam menentukan kebutuhan bahan/material serta peralatan yang dibutuhkan dalam penanganannya. Dari sisi internal pemerintah Kabupaten, penyelesaian dari masalah ini adalah dengan melakukan pengawasan atau monitoring secara berkala dan berkesinambungan. Pengawasan ini memerlukan biaya, sumber daya manusia dan waktu yang tidak sedikit. Salah satu solusi dari masalah ini adalah dengan melibatkan masyarakat untuk ikut berpartisipasi dalam memberikan informasi di lapangan khususnya masyarakat di Kabupaten Badung. 
Untuk membantu dan mempermudah masyarakat berpartisipasi secara aktif dengan biaya yang relatif murah dan hanya dengan menggunakan handphone maupun komputer tablet, maka diperlukan suatu sistem aplikasi yang dapat diakses secara mobile. Sistem Aplikasi yang dapat menampung informasi tentang permasalahan di lapangan dalam hal penanggulangan bencana, fasilitas umum yang rusak, dan lainnya yang dikirim oleh masyarakat kepada pemerintah dan mengandung informasi lokasi, serta kondisi riil di lapangan dalam bentuk Pengaduan Masyarakat.

Informasi lokasi diperoleh dari layanan berbasis lokasi, atau Location Based Service disingkat LBS. LBS adalah sebuah layanan yang menggunakan target lokasi sebagai nilai tambah layanan, hal mana target tersebut adalah sebuah entitas yang dialokasikan. Nilai tambah yang dimaksud dapat berupa tempat-tempat menarik disekitar lokasi, menunjukkan lokasi target pada peta, atau secara otomatis mengaktifkan suatu layanan bila mendekati atau menjauhi sebuah target lokasi[2]. Dalam hal ini, informasi lokasi yang diinformasikan adalah berupa titik koordinat lokasi pengaduan. Adapun model atau teknik penyampaian informasi yang digunakan dalam penelitian ini adalah Pull-based model[3], yaitu ketika user melakukan request layanan, lokasinya dilekatkan pada request oleh proxy lokasi kemudian diteruskan ke layanan LBS.

Dengan penggunaan sistem aplikasi pengaduan masyarakat berbasis lokasi yang dimanfaatkan dalam membangun partisipasi masyarakat, diharapkan dapat mendukung pengembangan kota cerdas seperti pada layanan pengaduan masyarakat di kota Bandung "Ngabandungan"[4], dan di kota Denpasar dengan "Pro Denpasar" nya[5].

Selanjutnya paper ini diorganisasikan dalam 5 bab sebagai berikut : bab 1 menjelaskan tentang rumusan masalah dan model aplikasi LBS, bab 2 menjelaskan tentang pengembangan kota cerdas, bab 3 memuat rancangan dan pembangunan sistem aplikasi, Bab 4 menjelaskan tentang hasil penelitian dan Bab 5 menjelaskan tentang kesimpulan hasil penelitian.

\section{Pengembangan Kota Cerdas}

\section{A. Pengembangan Kota Cerdas}

Kota Cerdas atau biasa dikenal sebagai Smart City, adalah sebuah istilah dalam menilai sebuah Kota yang telah berhasil memanfaatkan Teknologi Informasi sebagai alat dukung pemerintah maupun masyarakat dalam memberikan kemudahan-kemudahan pelayanan. Pada dasarnya Kota Cerdas adalah sebuah kota yang mampu mengetahui secara dini (unsur pintar, preventif) kebutuhan riil masyarakatnya sehingga senantiasa dapat terpenuhi / terantisipasi keinginan publik tersebut melalui beragam aplikasi dan inovasi teknologi informasi [6].

Menurut Gonzalez dan Rossi dalam New Trends for Smart Cities[7], layanan dan infrastruktur Kota Cerdas memerlukan karakteristik yang menarik dan interaksi dengan dan untuk warga yang memanfaatkannya. Menurut Indrajit dalam Kerangka Merancang dan Membangun Kota Cerdas di Seantero Nusantara, salah satu dari 6 (enam) komponen yang dipergunakan sebagai acuan dalam menilai kesiapan sebuah kota/kabupaten memasuki abad ekonomi digital adalah Sumber Daya Teknologi yang didalamnya termasuk beraneka ragam jenis aplikasi yang berfungsi untuk membantu masyarakat kota/kabupaten terkait dalam mendukung aktivitasnya sehari-hari.

Dalam hal ini, aplikasi dikembangkan menjadi sebuah sistem yang dapat memberikan masukan dan pertimbangan utamanya secara teknis kepada SKPD terkait dalam penanganan permasalahan di lapangan.

Berdasarkan parameter-parameter pendukung dalam usaha pengembangan suatu Kota menjadi Kota Cerdas yaitu :

1. Semakin luasnya penggunaan teknologi informasi di masyarakat dan semakin luasnya akses terhadap jaringan komunikasi pada masyarakat [6],

2. Sumber Daya Teknologi yang salah satunya adalah adanya Sumber Daya Teknologi berupa aplikasi yang berfungsi untuk membantu masyarakat dalam mendukung aktivitasnya sehari-hari [6], dan

3. Standar kebutuhan sistem aplikasi yang harus dipenuhi oleh setiap sistem aplikasi e-Government [8] :

a. Reliable, yaitu menjamin bahwa sistem aplikasi akan dapat berjalan dengan handal. Robust terhadap kesalahan pemasukan data, perubahan sistem operasi dan bug free.

b. Interoperable, yaitu menjamin bahwa sistem aplikasi akan dapat saling berkomunikasi serta bertukar data dan informasi dengan sistem aplikasi lain untuk membentuk sinergi sistem.

c. Scalable, yaitu menjamin bahwa sistem aplikasi akan dapat dengan mudah ditingkatkan kemampuannya, terutama penambahan fitur baru, penambahan user dan kemampuan pengelolaan data yang lebih besar.

d. User Friendly, yaitu menjamin bahwa sistem aplikasi akan mudah dioperasikan dengan user interface (antar muka pengguna) yang lazim berlaku di pemerintahan dan sesuai dengan kebiasaan bahasa dan budaya penggunanya.

e. Integrateable yaitu menjamin sistem aplikasi mempunyai fitur untuk kemudahan integrasi dengan sistem aplikasi lain.

Diperoleh kesimpulan bahwa sebuah sistem aplikasi yang dikembangkan dengan tujuan mendukung pengembangan Kota Cerdas seyogyanya memenuhi ketiga kriteria tersebut di atas.

Salah satu bentuk Sistem Pengaduan Masyarakat yang mendukung usaha pengembangan Kota Cerdas adalah Sistem Pengaduan Masyarakat dengan memanfaatkan teknologi informasi yang bersifat mobile atau dapat diakses darimana saja, dengan biaya yang relatif terjangkau, sederhana sehingga mudah dipahami dan digunakan, serta berbasis lokasi sehingga memungkinkan terjadinya interaksi dan saling bahu membahu dari unsur pemerintah dengan masyarakat dalam pemecahan suatu permasalahan yang memerlukan informasi lokasi yang akurat[9]. 


\section{B. Location Based Service}

Location Based Service adalah layanan berbasis lokasi yang memberikan informasi berdasarkan atas lokasi suatu perangkat mobile dengan berbagai model atau teknik penyampaian informasi lokasi. Adapun cara kerja sistem LBS dapat dibagi menjadi tiga model, yaitu Pull-based model, Poll-based model dan Push-based model [6] yang digambarkan seperti pada Gambar 1.

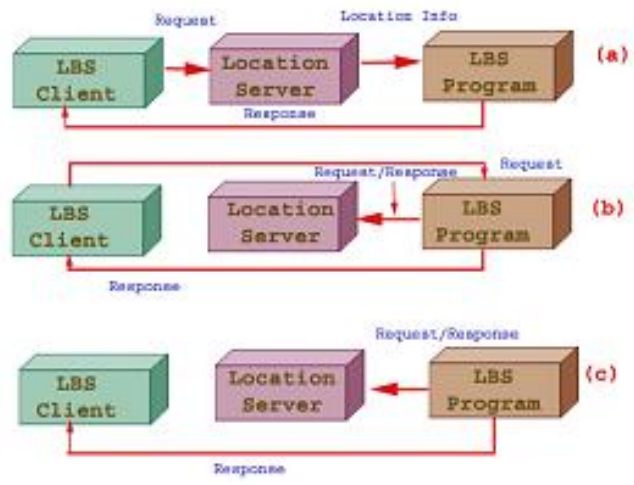

Gambar 1. Model cara kerja LBS[6]

a) Pull-based model

Location Proxy berada diantara aplikasi klien dan aplikasi LBS. Ketika klien memulai permintaan LBS pada aplikasi LBS, informasi lokasi dari klien dilekatkan pada permintaan (request) oleh Location Proxy dan diteruskan ke aplikasi LBS.

b) Poll-based model

Aplikasi LBS secara aktif mengirim permintaan lokasi melalui antar muka lokasi ke Server Lokasi (LS), yang bertanggungjawab dalam memperoleh lokasi yang diminta oleh klien. Pada model ini, Aplikasi LBS terus menerus menyimpan LS atau membuatkan daftar on demand LS dalam upayanya menjawab pertanyaan dari klien.

c) Push-based model

Aplikasi LBS mem push informasi lokasi kepada klien menurut preferensi klien dengan melacak keberadaan perangkat mobile milik pengguna.

Informasi lokasi dapat digunakan sebagai informasi pelengkap dari sebuah pengaduan sehingga sangat membantu pemerintah dalam penentuan lokasi termasuk penyediaan kebutuhan material dan peralatan dan pada akhirnya untuk mengambil keputusan dalam usahanya menyelesaikan masalah yang diadukan. Dalam hal ini, model yang digunakan adalah pull-based model, yaitu ketika user membuat sebuah pengaduan, koordinat lokasi dari tempat user atau perangkat yang digunakan diperoleh dari server lokasi, kemudian dilekatkan pada berkas pengaduan, sehingga menjadi informasi lokasi yang secara langsung dikirim dari lokasi pengaduan dibuat atau dikirim.

\section{Aplikasi Penyusun Sistem}

Dalam membangun sistem aplikasi pengaduan masyarakat dengan layanan Location Based Service ini, pengembangannya dibagi menjadi dua sisi yaitu sisi Server dan sisi Client. Pada sisi Server, dirancang dan dibangun sebuah aplikasi berbasis web yang mampu memberikan respon terhadap request dari Client dengan antarmuka web maupun mobile.

Pada sisi Server dikembangkan dengan Server Side Scripting PHP, dan pada Client berupa HTML dan Javascript. Sedangkan pada antarmuka mobile, sistem operasi yang digunakan adalah Android. Aplikasi dikembangkan dengan App Inventor 2 versi Offline.

Untuk menyediakan layanan informasi lokasi, dimanfaatkan layanan dari Google Map dan Geocoding pada aplikasi baik aplikasi web maupun mobile

\section{RANCANG BANGUN APLIKASI}

Sistem Aplikasi ini dirancang dan dibangun untuk kemudian dilakukan pengujian terhadap setiap fitur yang ada apakah telah berfungsi dengan baik sesuai dengan rancangan. Adapun urutan langkah yang diambil dalam proses ini seperti yang terlihat pada Gambar 2 berikut :

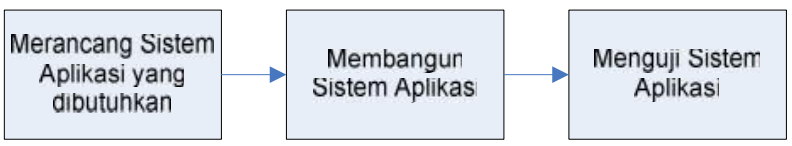

Gambar 2. Langkah-langkah Rancang Bangun Sistem

Ketiga langkah tersebut masing-masing dijabarkan sebagai berikut :

\section{A. Merancang Sistem Aplikasi yang dibutuhkan.}

Dalam merancang sebuah sistem aplikasi pengaduan masyarakat, terlebih dahulu dilakukan observasi dan pengenalan akan lingkungan kerja pemerintah daerah, khususnya di Kabupaten Badung termasuk tanggungjawab dari masing-masing Satuan Kerja Perangkat Daerah. Kemudian disusun bagaimana bentuk aplikasi yang tepat digunakan dalam lingkungan pemerintahan sekaligus dapat dijangkau secara relatif mudah oleh masyarakat berdasarkan kebutuhannya dalam mengetahui lokasi permasalahan di lapangan.

Aktor yang terlibat adalah Administrator Sistem, Admin Instansi Tujuan Pengaduan, Masyarakat dan Inspektur. Fitur yang diperlukan yaitu Melihat Pengaduan, Melaporkan Pengaduan, Update Bio Data, Manajemen User dan Manajemen Pengaduan. Rancangan ini disusun dengan terlebih dahulu mendesain diagram alir proses bisnis, menyusun diagram aliran Data seperti ditunjukkan pada Gambar 3,4 dan Gambar 5, serta merancang basis data.

\section{B. Membangun Sistem Aplikasi}

Arsitektur sistem aplikasi pengaduan masyarakat ini disusun dalam arsitektur Client-Server dengan aplikasi Server berbasis web dan aplikasi Client berbasis web dan mobile dengan sistem operasi android.

Perangkat Keras yang digunakan adalah mesin server yang diperoleh dengan mendaftar pada sebuah hosting. Pada Server ini dibangun aplikasi berbasis web dengan Server Side 
Scripting dan Database untuk menampung dan mengolah data user dan pengaduan. Akses ke aplikasi ini dapat dilakukan dengan menggunakan layanan web atau dengan browser dan dengan aplikasi mobile berbasis android.

Perangkat Lunak atau program yang digunakan adalah berbasis web dan berbasis mobile. Adapun struktur menu programnya masing-masing ditunjukkan pada Gambar 6 dan Gambar 7.

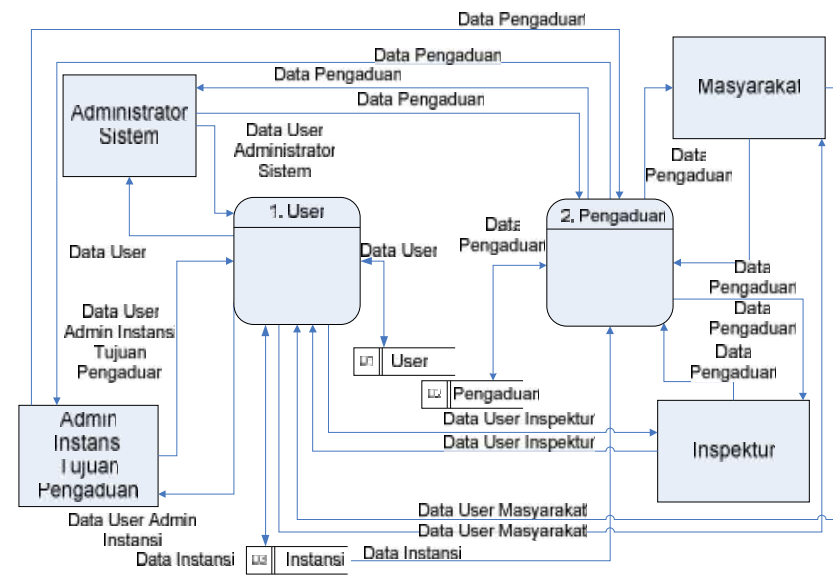

Gambar 3. DAD Level

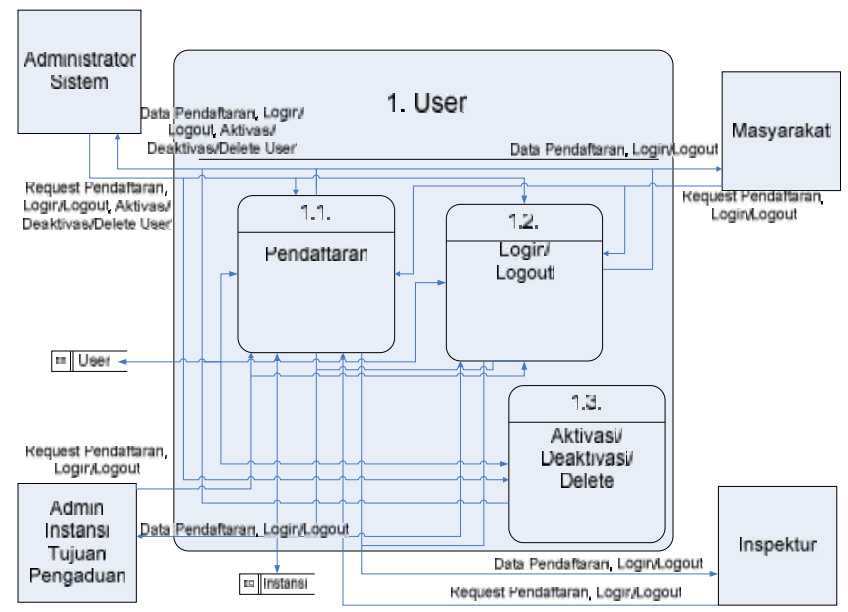

Gambar 4. DAD Level 1 (User)

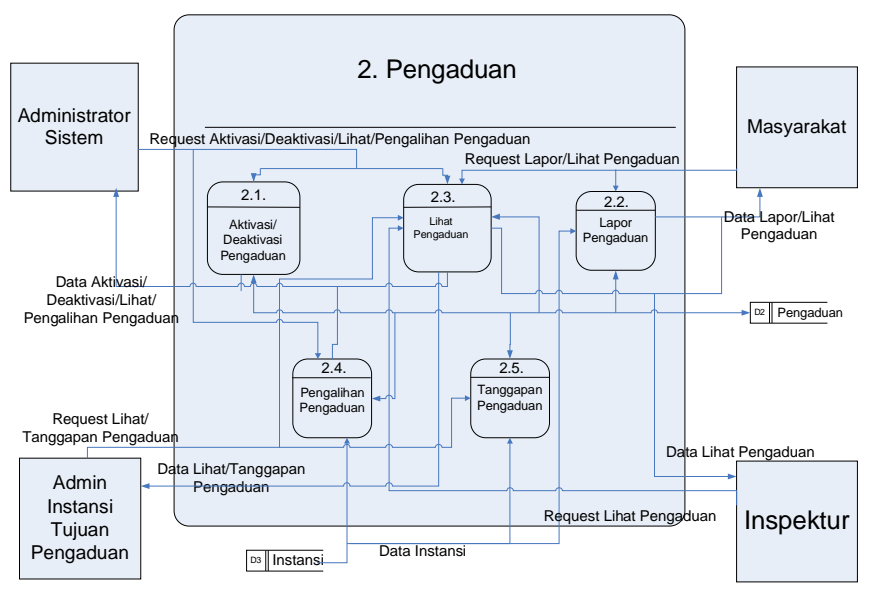

Gambar 5. DAD Level 1 (Pengaduan)
Administrator Sistem bertugas memanajemen seluruh user dan pengaduan termasuk mengarahkan pengaduan kepada instansi yang tepat. Admin Instansi Tujuan Pengaduan bertugas memanajemen pengaduan dan memberikan tanggapan status penanganan oleh instansinya.

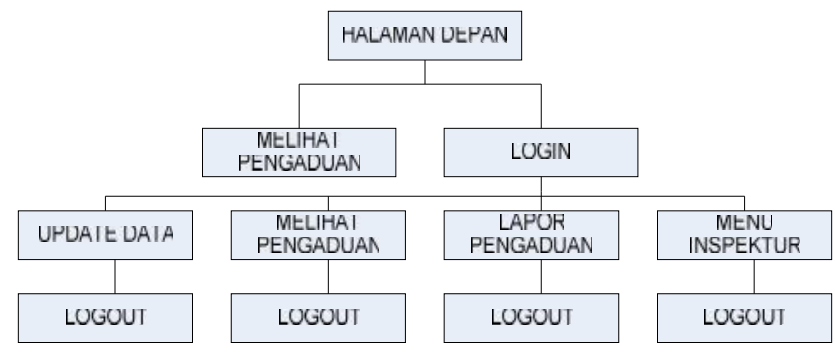

Gambar 6. Struktur halaman web

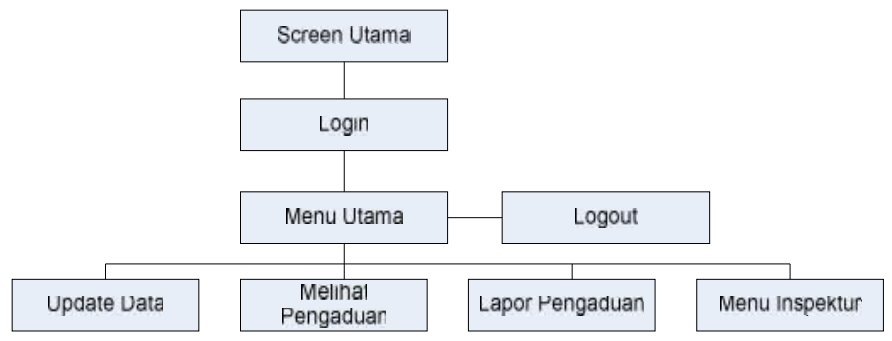

Gambar 7. Struktur aplikasi mobile

User Masyarakat memiliki hak untuk melakukan laporan pengaduan, dan mendapat tanggapan atas pengaduannya. Sedangkan User Inspektur memiliki hak untuk melakukan inspeksi terhadap setiap pengaduan dan menilai respon dan tanggapan dari User Instansi Tujuan Pengaduan.

Dari sisi User Masyarakat, sistem aplikasi ini memiliki beberapa fitur yaitu :

1. Melakukan pendaftaran untuk mulai menggunakan aplikasi (berdasarkan email valid)

2. Masuk ke dalam sistem dengan pasangan username dan password yang telah diaktifkan Admin. Masuk ke dalam sistem juga dapat dilakukan tanpa melakukan pendaftaran, yaitu dengan akun Social Media Facebook atau Twitter.

3. Melihat Daftar Pengaduan termasuk melihat pengaduan secara detil

4. Melaporkan Pengaduan baik melalui antar muka web maupun melalui aplikasi mobile berbasis Android HaloMangupura.

5. Update Data User yaitu melakukan update terhadap data pengguna.

Dari sisi User Administrator Sistem, sistem aplikasi ini memiliki beberapa fitur yaitu :

1. Update Data User

2. Manajemen User

- Aktif / Nonaktif User

- Delete User

3. Manajemen Pengaduan

- Aktif/Nonaktif Pengaduan

- Mengarahkan Instansi Tujuan Pengaduan 
Dari sisi User Admin Instansi Tujuan Pengaduan, sistem aplikasi ini memiliki beberapa fitur yaitu :

1. Update Data User

2. Manajemen Pengaduan

- Memberikan Tanggapan atas Pengaduan

Dari sisi User Inspektur, sistem aplikasi ini memiliki beberapa fitur yaitu :

1. Update Data User

2. Inspeksi Pengaduan

- Memantau Penanganan Pengaduan oleh Instansi Tujuan Pengaduan (Wajar/Lambat)

- Mencetak Data Pengaduan menurut Instansi

Selain fitur-fitur tersebut di atas, Sistem aplikasi ini juga telah menggunakan antarmuka Social Media seperti Facebook dan Twitter untuk masuk ke dalam sistem. Sehingga, User yang telah memiliki akun Facebook atau Twitter, tidak memerlukan proses pendaftaran dan aktivasi User, melainkan langsung dapat menggunakan aplikasi dengan data profil user yang diambil dari akun Social Media tersebut.

\section{Menguji Sistem Aplikasi}

Seluruh tugas dan wewenang aktor dalam sistem aplikasi ini diakomodir dalam fitur-fitur yang ada, setiap aplikasi baik yang berbasis web maupun mobile dilakukan pengujian. Adapun pengujian yang dilakukan dengan metode black box, yaitu setiap fitur dimasukkan input sesuai peruntukannya, kemudian dilihat output hasil proses sistem apakah sesuai dengan harapan atau tidak, seperti terlihat pada Gambar 8.

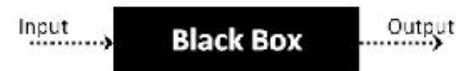

Gambar 8. Blackbox Testing

\section{HASIl DAN PEMBAHASAN}

Sistem aplikasi Location Based Service dalam usaha pengembangan Kota Cerdas telah dibangun dengan berbagai fitur dan kemudian dilakukan pengujian aplikasi. Contoh penggunaan mengikuti alur yang ditunjukkan pada Gambar 9 sebagai berikut :

1. User masyarakat melalui web/aplikasi mobile membuat akun pada sistem.

2. Dengan akun tersebut user masyarakat dapat melaporkan sebuah pengaduan yang kemudian di moderasi oleh admin sistem.

3. Laporan yang valid akan diteruskan kepada instansi tujuan laporan.

4. Admin Instansi Tujuan Pengaduan melakukan koordinasi internal instansi untuk pemeriksaan pengaduan untuk menentukan Pengaduan yang valid dan dinyatakan benar serta membuat tanggapan.

5. User Inspektur yang memiliki tugas mengawasi dan memantau kinerja instansi dalam menanggapi pengaduan dapat melihat seluruh pengaduan dan proses penanganannya. Tanggapan yang diberikan $>7$ hari dinilai "LAMBAT" sedangkan jika masih dalam rentang waktu 7 hari dinilai "WAJAR".

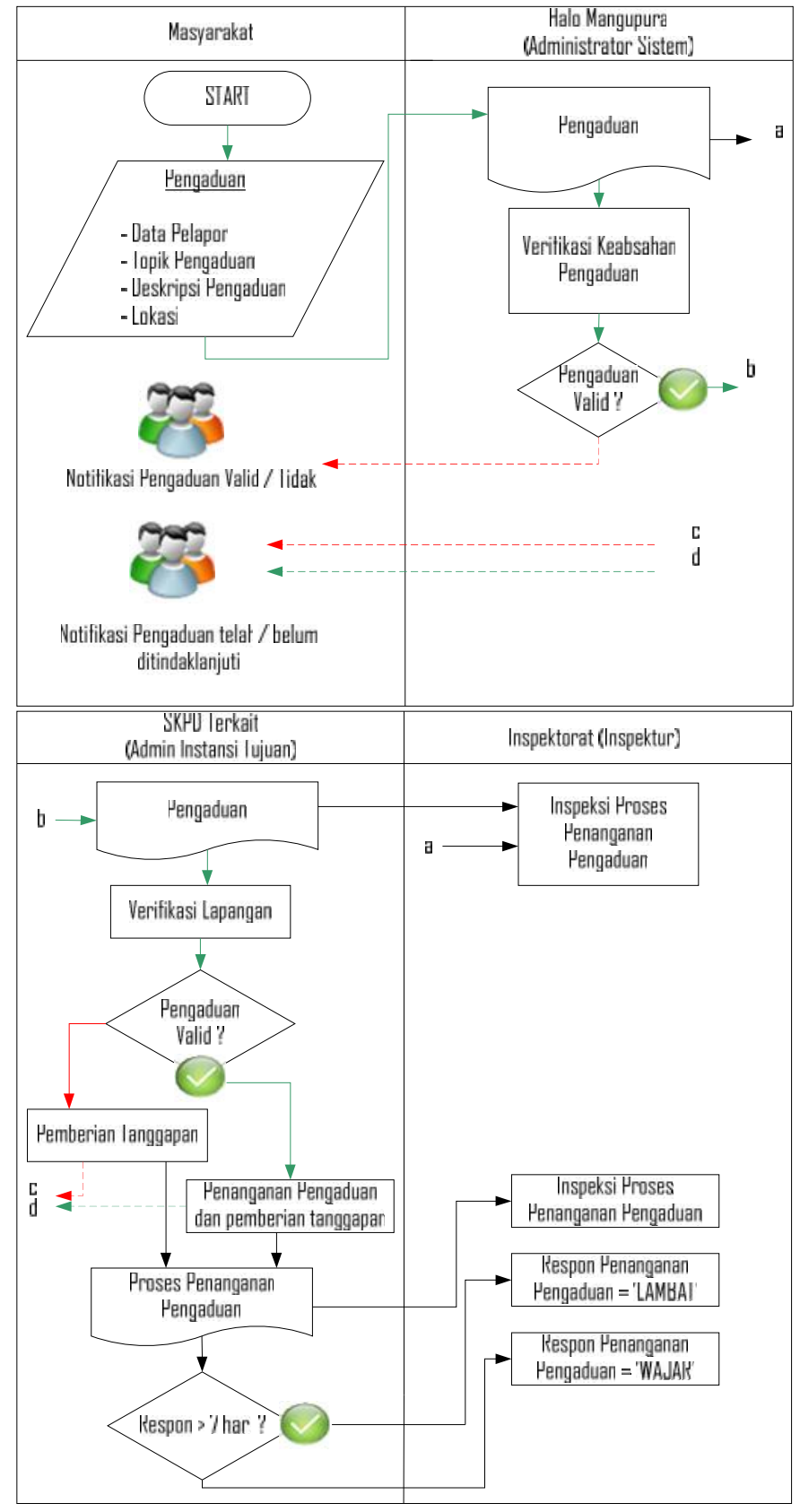

Gambar 9. Alur kerja penanganan pengaduan

Hasil pengujian secara keseluruhan adalah valid terhadap seluruh fitur yang ada untuk masing-masing user seperti terlihat pada Tabel I

TABEL I

HASIL UJI FITUR APLIKASI

\begin{tabular}{|c|c|c|c|}
\hline No. & Fitur & User yang terlibat & $\begin{array}{r}\text { Hasi } \\
\text { Uji }\end{array}$ \\
\hline 1. & Pendaftaran User & Semua & Valid \\
\hline 2. & Masuk ke dalam sistem & Semua & Valid \\
\hline 3. & Melihat Pengaduan & Semua & Valid \\
\hline 4. & Update data User & Semua & Valid \\
\hline 5. & Manajemen User & Admin Sistem & Valid \\
\hline 6. & Manajemen Pengaduan & $\begin{array}{l}\text { Admin Sistem dan } \\
\text { Admin Instansi }\end{array}$ & Valid \\
\hline 7. & Inspeksi Pengaduan & Inspektur & Valid \\
\hline
\end{tabular}


Penjelasan masing-masing pengujian fitur pada Tabel 1:

1. Pengujian dilakukan dengan mencoba mendaftar melalui antarmuka web atau aplikasi mobile dengan aktivasi melalui email. Hasilnya pendaftaran berhasil.

2. Pengujian dilakukan dengan mencoba Login melalui antarmuka web atau aplikasi mobile menggunakan password, atau akun Social Media. Hasilnya login berhasil.

3. Pengujian dilakukan dengan mencoba login, dan melihat secara detil pengaduan dari daftar pengaduan yang ada melalui antarmuka web atau aplikasi mobile. Hasilnya detil pengaduan dapat diakses.

4. Pengujian dilakukan dengan mencoba Update Data diri baik melalui antarmuka web atau aplikasi mobile. Hasilnya update data berhasil.

5. Pengujian dilakukan dengan login sebagai Admin Sistem, dan mengaktifkan/nonaktifkan user. Hasilnya user berhasil diaktifkan/dinonaktifkan.

6. Pengujian dilakukan dengan login sebagai Admin Sistem. Hasilnya pengaduan dapat diarahkan sesuai instansi yang menangani. Login sebagai Admin Instansi, memberikan tanggapan pada pengaduan yang ditujukan ke instansinya. Tanggapan oleh Admin Instansi berhasil disimpan dan tayang pada detil pengaduan.

7. Pengujian dilakukan dengan login sebagai Inspektur. Hasilnya data penanganan pengaduan dapat diakses dan dapat dicetak berdasarkan instansi

\section{KESIMPULAN}

Dalam penelitian ini diperoleh beberapa kesimpulan sebagai berikut :

1. Sistem aplikasi Client-Server Pengaduan Masyarakat guna mendukung pengembangan Kota Cerdas yang memanfaatkan layanan berbasis lokasi telah dibangun dengan fitur :

- Pendaftaran, Masuk sistem dengan pemanfaatan akun Email maupun Social Media.

- Pelaporan Pengaduan baik melalui browser maupun aplikasi mobile android.

- Melihat detail Pengaduan (Deskripsi, Lokasi dan File multimedia).

- Manajemen User dan Manajemen Pengaduan oleh Administrator Sistem.

- Manajemen Pengaduan oleh Admin Instansi Tujuan Pengaduan.

- $\quad$ Inspeksi Penanganan Pengaduan oleh Inspektur.

2. Melalui pengujian dengan black box testing, diperoleh hasil sistem telah berjalan dengan semestinya dan seluruh fitur yang ada berjalan dengan baik dan hasilnya memenuhi harapan sesuai dengan rancangan yang telah disusun.

\section{DAFTAR PUSTAKA}

[1] Dinas Perhubungan Komunikasi dan Informatika , Rencana Strategis Dinas Perhubungan Komunikasi dan Informatika Kabupaten Badung 2010-2015.

[2] Axel Kupper, Location-based Services Fundamentals and Operation, John Wiley \& Sons Ltd,2005.
[3] Sandeep Kumar, Mohammed Abdul Qadeer, Archana Gupta, Location Based Services using Android (LBSOID), Department of Computer Engineering Zakir Hussain College of Engineering and Technology Aligarh Muslim University, Aligarh 202002, India, 2009.

[4] Anonim. 2015. Website Aplikasi Ngabandungan oleh Walikota Bandung Ridwan Kamil. Tersedia di http://www.ridwankamil.net/ngabandungan. [diakses : 24 Maret 2015]

[5] Anonim. 2015. Website Pengaduan Rakyat Online Kota Denpasar. Tersedia di : http://www.pengaduan.denpasarkota.go.id. [diakses : 24 Maret 2015]

[6] Richardus Eko Indrajit, Kerangka Merancang dan Membangun KOTA CERDAS di Seantero Nusantara, EKOJI999 Nomor 001, 9 September 2012 ICT Pura.

[7] Juan Andrés Alonso González (ATOS) and Andrea Rossi (ATOS), New Trends for Smart Cities, OPEN CITIES, 2011.

[8] Dinas Perhubungan Komunikasi dan Informatika, Rencana Detail Sistem Informasi Pemerintah Kabupaten Badung dan Rencana Strategis Pengembangan E-Government di Kabupaten Badung 2010-2015.

[9] Luca Calderoni, Dario Maio and Paolo Palmieri, Location-aware Mobile Services for a Smart City: Design, Implementation and Deployment, Journal of Theoretical and Applied Electronic Commerce Research ISSN 0718-1876 Electronic Version VOL 7 / ISSUE 3 / DECEMBER $2012 / 74-87$ 